\title{
Analysis of Financial Statements for Prediction of Business Sustainability in Rwanda: A Case of Banque Populaire Du Rwanda Ltd
}

Jean Bosco Harelimana*

Institut d'Enseignement Superieur de Ruhengeri Musanze, Musanze, Rwanda

\begin{abstract}
Banks are the company which serves the society on the financial services. Banque populaire du Rwanda (BPR) is the one in providing such activity in Rwanda. Different means are provided to consider BPR activities. The main aim to this study is to analyze the financial indicators and business sustainability determinant of predicting future outlook of BPR Ltd during the period 2011 to 2015. BPR improves its services if it is aware of the sustainability index and the financial indicators as well as the relationship between financial indicators and factors of BPR business sustainability. After the employment of techniques in collecting both primary and secondary data on the sample of 83 out of 1606 total population, the financial indicators and business sustainability were analyzed using Bank Analysis Fact sheet (BAFs) and Statistical Package for Social Sciences (SPSS). The results indicate there are indications that the positive relationship is only true for low and moderate sustainability performers. The recommendation such as BPR recapitalization, cost cut-off for unnecessary expenditure and more were suggested as strategies for business sustainability.
\end{abstract}

Keywords: Financial Statement Analysis, Predicting, Business Sustainability, Banque Populaire du Rwanda

\section{Background}

The main objective of financial statements is to provide information about the financial position, sustainability and changes in financial position of an enterprise that is useful to a wide range of users in making economic decisions for business sustainability or going concern. But the information as is provided in the financial statements is not adequately helpful in drawing a meaningful conclusion regarding to the business sustainability, i.e., whether a business is performing, or Not. Thus, an effective analysis and interpretation of financial statements is required. For that reason, after preparation of the financial statements, one may be interested in analyzing the financial statements with the help of different tools such as comparative statement, common size statement, ratio analysis, trend analysis, fund flow analysis, cash flow analysis, etc.

Analysis of a financial is important to various parties (Internal and external users) such as shareholders, Government, tax authorities, creditors, potential investors, and regulatory agencies, and others... because the business sustainability can be detected from its financial analysis. This means that, a sustained success will depend on how well business is performing based on the analysis of financial statements [1].

Financial indicators have long been the foundation for business sustainability measurement and there is a meaningful relationship between analysis of financial indicators and predicting its business performance. Otley argues that financial measure of performance is very crucial as it serves as a tool of financial management, a major objective of a business organization, and a mechanism for motivation and control within an organization [2]. The main difficulty is that many companies do not carry out their financial statements, or others do not analyze it. The problem associated with this, is that business strategies drawn by the decision makers are based on the poor measurement of financial indicators. The companies fail to perform due to the fact that they do not pay attention to the company financial statements for forecasting its business performance.

A financial institution like BPR Ltd has to analyses its financial statements, to be able to monitor and control their specific activities; to predict future internal and external states; to monitor state and behavior relative to its goals; to make decisions within needed time frames; and to alter the firm's overall orientation and/or behavior.

According to BNR, BPR is ranked on the second by assets, second by deposit and 3 by loans portfolios. It is also a leading retail bank in Rwanda, but this is not the case for the sustainability of its business [3]. Because, having reviewed the BPR financial statements which are prepared in accordance with International Financial Reporting Standards and Law No. 7/2009 relating to companies, since 2008 while BPR became a commercial bank, it didn't divided the dividends to the shareholders anymore. In additional to, it's net incomes are yet below to those of other commercial banks which has lower assets, loans, and deposits than the BPR Ltd. This has been affected the BPR business strategies while planned the recapitalization scenario in 2014 . According to prior-study made by the research to the BPR, this bank has been suspended to loan in the ended 2013. It was subjected a number of customers to run out of the BPR. Add that, a prior survey on the BPR financial report revealed that the company is counting three years without making a profit, nor distributing dividend to the shareholders. Prior survey showed that BPR is not adequately capitalized to meet its obligations. According to the CEO's declaration through the BPR strategic plan, stated that in 2008, BPR had 25\% Rwanda's market share in loans and local currency deposits. But due to the adequately capitalized bank such as BK, due also to the new entrants into market competitively experienced bank including $\mathrm{KCB}$ and Equity Bank (both from Kenya), again from the introduction of a new cooperatives umbrella of SACCOs which targeting SMEs and individuals which have been traditionally BPR core markets, that market share has shrunk down to $14 \%$ (as at 30 June 2013), and it is still dropping down [4].

*Corresponding author: JHarelimana JB, Institut d'Enseignement Superieur de Ruhengeri Musanze, Musanze, Rwanda, Tel: +250 788357 6; E-mail: harelijordan@yahoo.fr

Received January 09, 2017; Accepted February 13, 2017; Published February 20, 2017

Citation: Harelimana JB (2017) Analysis of Financial Statements for Prediction of Business Sustainability in Rwanda: A Case of Banque Populaire Du Rwanda Ltd Bus Eco J 8: 288. doi: 10.4172/2151-6219.1000288

Copyright: $\odot 2017$ Harelimana JB. This is an open-access article distributed under the terms of the Creative Commons Attribution License, which permits unrestricted use, distribution, and reproduction in any medium, provided the original author and source are credited. 
Many of BPR branches are located far away from business areas; hence BPR has also been losing customers through poor service delivery that fails to meet their expectations.

Those are the serious issues affect negatively the performance of a business. It could also lead the BPR to run out the banking business, also to the inadequate resources allocation which the final results being the poor performance of the Business organization. In these state of affairs, it is suspicious to ensure on BPR outlook of its business performance. Analysis and interpretation of financial statements is an important tool in assessing the prediction of business performance in BPR. This research will assess whether there is a relationship between financial indicators and the determinants of predicting business sustainability in BPR Ltd.

The study is focused on the following hypothesis:

a. Profitability ratios, Liquidity Ratios, efficiency ratios, leverage ratios and market value ratios are the indicators of financial analysis of BPR Ltd.

b. Payout ratio, retention ratio, internal growth rate and sustainable growth rate are the factors of the BPR business sustainability.

c. The financial analysis indicators explain positively the prediction of business sustainability determinants in BPR Ltd.

\section{Objectives}

In general, the research is to analyze the financial statement for prediction of business sustainability in Rwanda. The study will emphasis and ensure that the highlighting specific objectives are achieved.

1. To determine the financial analysis indicators of the BPR Ltd; Ltd;

2. To analyze the determinants of the business sustainability of BPR

3. To measure the relationship between financial indicators and business sustainability determinants of the BPR.

\section{Literature Review}

Financial indicators are statistics extensively used to monitor the soundness, stability and performance of various sectors of the economy, (Jane et al., 2008). Their usefulness lies in their ability to provide insight into the relationships among economic and financial statistics such as debt, assets, liabilities, net worth, incomes and output, in other words, enhancing the analytical content of these statistics taken individual.

A financial statement is a written report which quantitatively describes the financial health, strength, performance and liquidity of a company. Bashir defines a financial statement (or financial report) as a formal record of the financial activities and position of a business, person, or other entity. Relevant financial information is presented in a structured manner and in a form easy to understand. A balance sheet, also referred to as a statement of financial position, reports on a company's assets, liabilities, and owners' equity at a given point in time. This includes a statement of comprehensive income, referred to as a statement of profit or loss, and often also includes a statement cash flow and a statement of changes in equity. Financial statements reflect the financial effects of business data, transactions and events on the entity [5].

Financial data consists of pieces or sets of information related to the financial health of a business. The pieces of data are used by internal management to analyses business performance and determine whether tactics and strategies must be altered.

Financial statement analysis (or financial analysis) is the process of reviewing and analyzing a company's financial statements to make better economic decisions. Financial statement analysis is likely to evaluate the financial status of a company. An accountant will perform several duties, like profit and loss analysis, oversee management practices, and prepare financial statements.

A financial ratio or accounting ratio is a relative magnitude of two selected numerical values taken from an enterprise's financial statements. Financial ratios are mathematical comparisons of financial statement accounts or categories [6]. These relationships between the financial statement accounts help investors, creditors, and internal company management understand how well a business is performing and areas of needing improvement [6]. According to Wozniewska $\mathrm{G}$, Ratio analysis is a useful management tool that will improve your understanding of financial results and trends over time, and provide key indicators of organizational performance [7]. The following are the types of financial ratios analysis:

\section{Profitability}

Bhole and Jitendra a profitability ratio is a measure of profitability, which is a way to measure a company's performance. Common profitability measures include the Net Income Margin (NIM), which is the ratio of net income to sales, and Gross Profit Margin (GPM), which is the ratio of gross profit to sales. Others profitability ratios used in analyzing a company's financial include gross operating margin (OM), return on assets (ROA), return on equity (ROE), return on sales (ROS) and return on investment (ROI).

\section{Liquidity}

In accounting, the term liquidity is defined as the ability of a company to meet its financial obligations as they come due. Liquidity refers to an enterprise's ability to pay short-term obligations; the term also refers to its capability to sell assets quickly to raise cash. On other hand, Solvency refers to an enterprise's capacity to meet its long-term financial commitments. Moreover, the solvency ratio quantifies the size of a company's after tax income, not counting non-cash depreciation expenses, as contrasted to the total debt obligations of the firm.

\section{Efficiency}

Gibson and Charles the efficiency ratio, a ratio that typically applies to banks, in simple terms is defined as expenses as a percentage of revenue (expenses/revenue), with a few variations. The most common efficiency ratios include: Total Asset Turnover and Inventory Turnover [3].

\section{Leverage}

Robinson, states a leverage ratio as any one of several financial measurements that look at how much capital comes in the form of debt (loans), or assesses the ability of a company to meet financial obligations [8]. The most common leverage ratios include; Debt Ratio, and Debt to Equity Ratio.

\section{Market value}

According to Abbas, Market value ratios are used to evaluate the current share price of a publicly-held company's stock. Market ratios allow the analyst to understand how other investors feel about owning a share of a company's stock. 
According to Hakensen, Business sustainability is often defined as managing the triple bottom line, as a process by which companies manage their financial, social and environmental risks, obligations and opportunities. These three impacts are sometimes referred to as profits, people and planet [9]. Sustainability is broadly defined as meeting the needs of the present generation without compromising the ability of future generations to meet their own needs.

\section{Pay-out ratio}

The payout ratio is the percentage of net income that a company pays out as dividends to common shareholders [10].

\section{Retention ratio}

According to BNR, the retention ratio refers to the percentage of net income that is retained to grow the business, rather than being paid out as dividends [3].

\section{Internal growth rate}

An economist James Tobin, of Yale University states that an internal growth rate is the highest level of growth achievable for a business without obtaining outside financing, and a firm's maximum internal growth rate is the level of business operations that can continue to fund and grow the company [11].

\section{Sustainable growth rate}

According to James Tobin, Sustainable growth is defined as the annual percentage of increase in sales that is consistent with a defined financial policy [11].

Various studies have been carried out on financial indicators and determinants for predicting business sustainability; here is some review of them.

Saleem and Rehman, sought to reveal the relationship between financial indicators and sustainability for long run [11]. He has acquired the Liquidity ratios and Profitability ratios calculated from financial statement as independent variable and dividend payout to the shareholder as dependent variable. The main results of the study demonstrate that each ratio (variable) has a significant effect on the sustainability of business with differing amounts and that along with the liquidity ratios in the first place. He has concluded that Liquidity and Profitability ratios play an important role for forecasting the sustainability of a business.

Al-Tamimi and Obeidat identified the most important variables which affect the Capital Adequacy of Commercial Banks of Jordan in Amman Stock Exchange for the period from 2000 to 2008 [10]. The study shows that there is a statistically significant positive correlation between the degree of capital adequacy in commercial banks and the factors of internal growth, and the return on share, and there is an inverse relationship not statistically significant between the degree of capital adequacy in commercial banks and factors of the capital risk, credit risk, and the rate of force- revenue. In his conclusion, he stated that the size of capital contribute on the sustainability of business in current and in future.

Almazari in his study attempted basically to predicting the sustainability of business of seven Jordanian commercial banks on the basis of financial information of the period of 2005-2009, by using simple regression in order to estimate the impact of independent variable represented by; the deposits, credits, assets, profit and operational efficiency and took dependent variable as sustainability growth and internal growth calculated from net income [6]. It was found that banks with higher the deposits, credits, assets, profit are mostly sustainable in business, than bank with low the deposits, credits, assets, profit. Also found that there exists a positive correlation between financial ratio and its sustainability on market and competition, which was also confirmed with regression analysis that sustainability of bank is greatly influenced by these independent factors.

By this time, this study would concentrate financial line for analysis of financial statements for predicting business sustainability in Rwanda, with empirical study of BPR Ltd, 2011-2015. With support from financial line sustainability measures and majority of previous empirical findings, we hypothesize that: Ceteris paribus, there is a positive relationship between ...financial statements and financial indicators for predicting business sustainability of BPR Ltd.

\section{Methodology}

The research is exploratory and explanatory in nature. The methodology regarding this study is based on different method, qualitative and quantitative methods, among which various sources of information on financial statement and financial indicators for predicting the business sustainability were compared and analyzed. Both primary and secondary data were collected and then analyzed through BAFs and SPSS. A structured questionnaire was designed for 83 from 1606 total population under this study.

\section{Data collection and analysis}

Data was collected from a field using questionnaires, semi structured interviews, observation and documentation by 83 personnel and board of director's members of BPR. The total population under this study is 1606 where a sample of 83 personnel of BPR Ltd was calculated using Alain Bouchard formula as cited by Sabiti.

\section{Instruments}

The collected data were used to achieve the research purpose. Data were changed into meaningful information for easy interpretation and understanding. It was done through various forms such as texts, tables, and figures. The different techniques were used such as editing, coding, tabulation. The main techniques to be used are the techniques of financial statements analysis for, such as Ratio Analysis, Trend Percentages; common-size statements, mathematic data comparison as vertical and horizontal analysis. Company financial statement is analyzed to assess if the is any relationship between financial soundness indicators of BPR and its business performance. The variables have to be analyzed as well to test the hypothesis. The detailed definitions and the expected signs of their impact are given in literature review. The data collected have been checked for any errors and omissions. After the checking, the data have been coded and analyzed using Bank Analysis Factsheet (BAFs) and Statistical Package for Social Sciences (SPSS). The indicators of financial analysis of BPR were Profitability ratios, Liquidity Ratios; efficiency ratios, leverage ratios and market value ratios (Table 1 ).

The prediction of business performance of BPR Ltd has been based of interpretation and analysis of financial statements and financial sustainability indicators provided automatically by Factsheet BRS in figures or in graphic. Those BPR business sustainability determinants are grouped into four categories: Pay-out ratio, retention ratio, internal growth rate and sustainable growth, and each category of indicator have sub indicators named ratio (Table 2). 
Citation: Harelimana JB (2017) Analysis of Financial Statements for Prediction of Business Sustainability in Rwanda: A Case of Banque Populaire Du Rwanda Ltd. Bus Eco J 8: 288. doi: 10.4172/2151-6219.1000288

\section{Models and techniques}

The regression analysis was used in this study to measure the relationship between financial indicators and business sustainability of BPR Ltd. The correlation matrix was extracted using SPSS version 18.0 to show the correlation between roles of financial statement to forecasting sustainability of BPR Ltd as its determinants were shown in the conceptual framework. The regression analysis was used to establish the relationship between the variables of the study. The following regression model was used: $y=\beta_{0}+\beta_{1} x_{1}+\ldots+\beta_{\infty} x_{\infty+\epsilon}$ where y represents the dependent variable means Business sustainability determinants such as Payout ratio, retention ratio, internal growth rate and sustainable growth rate, and $\beta_{0}$ is the constant term represent the model parameters of coefficients $x_{1}$ is the profitability ratios, liquidity ratios, efficiency ratios, leverage and $x_{5}$ market value ratio and epsilon is the error terms.

\section{Data Analysis, Presentation and Interpretation}

The personnel under BPR Ltd financial sector is predominated

\begin{tabular}{|c|c|c|c|}
\hline \multicolumn{4}{|c|}{ Indicators of Financial Analysis of BPR } \\
\hline & $\begin{array}{l}\text { Financial } \\
\text { Indicators }\end{array}$ & Significant of determinant & Formula \\
\hline 1 & Profitability ratios & $\begin{array}{l}\text { The ability of a business to earn a } \\
\text { profit. It is a measure of profitability, } \\
\text { which is a way to measure a company's } \\
\text { performance }\end{array}$ & $\begin{array}{l}\text { 1. Gross Margin=Gross Profit/Net Sales *100 } \\
\text { GM=GP/NS *100 } \\
\text { 2. Operating Margin=Operating Profit/Net Sales *100 } \\
\text { OM=OP/NS *100 } \\
\text { 3. Return on Assets=Net Income/Assets *100 } \\
\text { ROA=NI/A *100 } \\
\text { 4. Return on Equity=Net Income/Shareholder Investment *100 } \\
\text { ROE=NI/SI *100 }\end{array}$ \\
\hline 2 & Liquidity Ratio & $\begin{array}{l}\text { Enterprise's ability to pay short-term } \\
\text { obligations; the term also refers to its } \\
\text { capability to sell assets quickly to raise } \\
\text { cash }\end{array}$ & $\begin{array}{l}\text { 1. Current Ratio=Current Assets } \div \text { Current Liabilities } \\
C R=C A / C L^{*} 100 \\
\text { 2. Acid Ratio }=(\text { Cash \& Cash Equivalents + Short-Term Investments + Accounts Receivable }) \div \\
\text { Current Liabilities } \\
\text { AR }=(C C E+S T I+A R) / C L^{*} 100 \\
\text { 3. Total loans to Total Asset Ratio }(T L T A)=T L T A=\text { Total Loans/Total Assets } \\
\text { 4. Liquid Assets to Total Deposit Ratio }(L A T D)=L A T D=\text { Liquid Asset/Customer Deposit } \\
\text { 5. Total Loans to Deposit Ratio }(T L T D)=T L T D=\text { Total Loans/Total Deposit }\end{array}$ \\
\hline 3 & Efficiency ratio & $\begin{array}{l}\text { Company's ability to use its assets } \\
\text { and manage its liabilities effectively. } \\
\text { Expenses as a percentage of revenue } \\
\text { (expenses/revenue), with a few } \\
\text { variations }\end{array}$ & $\begin{array}{l}\text { Efficiency Ratio=Expenses }(E) / \text { Revenue }(R) \text {. } \\
\text { Total operating expenses/Total operational income } \\
\text { 1. Net Interest Income=Interest Expenses/Interest Income } \\
\text { 2. Accounts Receivable Turnover=Revenue (R)/Average Accounts Receivable (AAR) } \\
\text { 3. Accounts Payable Turnover=Interest Expenses (IE)/Average Accounts Payable (AAP) } \\
\text { 4. Total Asset Turnover=Revenue (R)/Average Total Assets (ATA) }\end{array}$ \\
\hline 4 & Leverage ratio & $\begin{array}{l}\text { Assesses the ability of a company } \\
\text { to meet financial obligations, Both } \\
\text { long-term and short-term creditors are } \\
\text { concerned. It indicates the firm's risk } \\
\text { exposure in meeting its debt obligations. }\end{array}$ & $\begin{array}{l}\text { 1.Debt Ratio }(\mathrm{DR})=\text { Total Liabilities }(\mathrm{TL}) / \text { Total Assets }(\mathrm{TA}) \\
\text { 2. Debt-to-Equity }(\mathrm{DtE})=\text { Total Liabilities }(\mathrm{TL}) / \text { Total Equity }(\mathrm{TE}) \\
\text { 3. Equity Ratio }(\mathrm{ER}) \mathrm{OR} \text { Equity to Asset Ratio }(\mathrm{EQTA})=\text { Total Equity }(\mathrm{TE}) / \text { Total Assets }(\mathrm{TA}) \\
\text { 4. Equity to Loan Ratio }(\mathrm{EQL})=E Q L=T o t a l \text { Equity/Total Loans } \\
\text { 5. Non- performing Loans to Total Loan Ratio }(\mathrm{NPTL})=\mathrm{NPTL}=\text { Non-performing Loans/Total Loans }\end{array}$ \\
\hline 5 & $\begin{array}{l}\text { Market value } \\
\text { ratios }\end{array}$ & $\begin{array}{l}\text { Demonstrate the relationship between } \\
\text { the price per share and its earnings, } \\
\text { growth and assets }\end{array}$ & $\begin{array}{l}\text { 1. Price-Earnings Ratio (P/E Ratio)=Price per share or Market Value Price per share/Earnings per } \\
\text { share } \\
\text { Whereas: } \\
\text { Earnings per share=Net Income/Number of Shares Outstanding } \\
\text { 2. Market-to-Book Ratio=Price per share or Market Value Price per share/Book Value per share } \\
\text { Whereas: } \\
\text { Book Value per share=Total Owners' Equity/Number of Shares Outstanding }\end{array}$ \\
\hline
\end{tabular}

Source: Designed by the researcher, November 2016

Table 1: Treatment of indicators of financial analysis of BPR Ltd.

\begin{tabular}{|c|c|c|c|}
\hline \multicolumn{4}{|c|}{ BPR BUSINESS sustainability DETERMINANTS } \\
\hline & $\begin{array}{l}\text { Business sustainability } \\
\text { determinant }\end{array}$ & Significant of determinant & Formula \\
\hline 1 & Dividend Pay-out Ratio & $\begin{array}{l}\text { The percentage of net income that a } \\
\text { company pays out as dividends to common } \\
\text { shareholders }\end{array}$ & $\begin{array}{l}\text { Pay-out Ratio }=(\text { Total Dividends Paid }) /(\text { Net Income }) \\
\text { Pay-out Ratio }=(\text { Total Dividends }(\text { Common and Preferred }) \text { per Share }) /(\text { Earnings } \\
\text { per Share })\end{array}$ \\
\hline 2 & $\begin{array}{l}\text { Retention Rate or plowback } \\
\text { ratio }\end{array}$ & $\begin{array}{l}\text { The percentage of income that a company } \\
\text { reinvests into its own operations. In other } \\
\text { words, it is the percentage of net income } \\
\text { that a company does not pay-out as } \\
\text { dividends. }\end{array}$ & $\begin{array}{l}\text { Retention Rate }=(\text { Net Income }- \text { Dividends Distributed }) / \text { Net Income } \\
\text { Earnings Retention Ratio or Plowback ratio= } \\
\text { =Plowed back gross profits/total gross profits } \\
=\text { Total Gross Profits-Pay-out ratio } \\
=(\text { Total Net Profit/Number of Total share })-(\text { Dividend/Share })\end{array}$ \\
\hline 3 & Internal Growth Rate & $\begin{array}{l}\text { Internal Growth Rate (IGR) is the highest } \\
\text { growth rate a firm can achieve without } \\
\text { considering or taking in to account of any } \\
\text { external sources or financing Funds }\end{array}$ & $\begin{array}{l}\text { 1. Internal Growth rate }(I G R)=R O A \times \text { Retention Ratio/(1-(ROA x Re } \\
\text { Whereas: } \\
\text { ROA=Net Profit/Total of Assets of the firm } \\
\text { Retention Ratio=1 - Dividend payout of the firm }\end{array}$ \\
\hline 4 & Sustainable Growth Rate & $\begin{array}{l}\text { The sustainable growth rate represents } \\
\text { how quickly a company can expand using } \\
\text { only its own sources of funding. }\end{array}$ & SGR=Return in Equity *(1-Dividend Payout Ratio) \\
\hline
\end{tabular}

Source: Designed by the researcher, November 2016

Table 2: BPR Ltd business sustainability determinants. 
by male with the percentage of $77 \%$ while female has only $23 \%$ of ownership of 83 respondent including employees daily involving in finance, Executive Management Team and board members' shareholders representatives (as owners) selected from the Banque Populaire du Rwanda Limited according to table 18 above.

\section{The role of analyzing financial statement for forecasting sustainability of BPR Ltd}

In the literature, for predicting sustainable business requires effective and deep analysis of financial management. The BPR Ratio analysis is a useful management tool that will improve shareholders and staff understanding of financial results and trends over time, and provide key indicators of business sustainability. Decision makers should use ratio analysis to pinpoint strengths and weaknesses from which strategies for forecasting BPR sustainability. Shareholders and investors may use ratio analysis to anticipate their earning and its shares' growth in the future. Thus, to further ascertain the role of analyzing financial statement for forecasting sustainability of BPR Ltd, respondents were asked to indicate the role of analyzing financial indicators for BPR sustainability determinants.

The major reasons for why analyzing financial statement in forecasting sustainability, the respondents were to determine dividend to be distributed (89\%). Improve Sustainable Growth (88\%), Determine Retention on market price per share (81\%), Improve Internal Growth/ self-financing $(75 \%)$ and Supporting in decision making and goal realization (64\%), attracting current and new potential investors (64\%), Efficiency utilization of resource to generate Profit (61\%), and Effective planning (47\%) as asserted by different literatures in every organization the overall aim is to make profit [12-14].

\section{Financial indicators analysis of BPR Ltd}

Financial indicators which were analyzed in this research was to evaluate various aspects of BPR's operating and financial performance such as its profitability, liquidity, profitability, efficiency, leverage and market value ratio.

Profitability ratios: Profitability ratios indicate the ability of the BPR Ltd to earn a profit. It is a measure of profitability, which is a way to measure a company's performance. Secondary data was used for the period of 4 years ended 31 December 2015 for analyzing the profitability ratios of the BPR Ltd (Table 3 ).

In computing Operating Margin ratio, tabulated data above shows positive results. On Gross Margin, the tabulated data shows a negative results, especially in year 2015, 2013 and 2012, where ratios are $-6.01 \%,-42.02 \%$, and $-1.16 \%$ respectively. This means that BPR Ltd was recognized gross loss for these years. On Return on Assets, the tabulated data show negative results, especially in year 2015, 2013 and 2012. This means that, there were no any return recognized on the Assets, hence loss for these years. Return on Equity, the tabulated data 23 above shows a negative results, especially in year 2015, 2013 and 2012 , where ratios are $-11.97 \%,-33.77 \%$ and $-4.98 \%$ respectively. This means that, there were no any return recognized on the Shareholder's equity, hence loss for these years. For other remaining years of 2014 and 2011, the table revealed that a positive Gross Margin was recognized by BPR, respectively as $5.55 \%$ and $10.74 \%$.

Liquidity ratios: Liquidity ratios indicate BPR's ability to pay short-term obligations; the term also refers to its capability to sell assets quickly to raise cash. A normal and BNR required rate are: maximum $80 \%$ on Total Loans to Deposit Ratio, and minimum of $20 \%$ for Liquid Assets to Total Deposit Ratio [3] (Table 4).

Efficiency ratios: Efficiency ratios indicate the company's ability to use its assets and manage its liabilities effectively. Expenses as a percentage of revenue (expenses/revenue), with a few variations. A normal and BNR required rate is a maximum of $75 \%$ on the total expenses to revenues [3] (Table 5).

Leverage ratios: Analysis of leverage ratio for BPR Ltd is to assess its ability to meet financial obligations; both long-term and short-term creditors are concerned. It indicates the firm's risk exposure in meeting its debt obligations. A normal and BNR required rate is a maximum of $5 \%$ on Non-Performing Loans ratio [3] (Table 6).

Market value ratios: Market value ratios indicate the relationship between the price per share and its earnings, growth and assets for the BPR Ltd (Table 7).

Capital adjustment ratios: The BNR as regulators track a bank's Capital adequacy to ensure that it can absorb a reasonable amount of loss and complies with statutory Capital requirements. It is decided by central banks and bank regulators to prevent commercial banks from taking excess leverage and becoming insolvent in the process. The criteria for the stress tests on assets quality used two capital measures as the relevant metric:

\begin{tabular}{|c|c|c|c|c|c|c|}
\hline Profitability ratios & Formula & 2015 & 2014 & 2013 & 2012 & 2011 \\
\hline Operating Margin & $\mathrm{OM}=\mathrm{OP} / \mathrm{NS} * 100$ & 122.58 & 124.58 & 126.63 & 129.23 & 136.45 \\
\hline Gross Margin & $\mathrm{GM}=\mathrm{GP} / \mathrm{NS}$ *100 & $(6.01)$ & 9.19 & $(42.02)$ & $(1.16)$ & 12.78 \\
\hline Return on Assets & $\mathrm{ROA}=\mathrm{NI} / \mathrm{A} * 100$ & $(1.15)$ & 0.58 & $(3.28)$ & $(0.47)$ & 1.05 \\
\hline Return on Equity & $\mathrm{ROE}=\mathrm{NI} / \mathrm{SI}$ *100 & (11.97) & 5.51 & $(33.77)$ & $(4.98)$ & 10.74 \\
\hline
\end{tabular}

Source: BPR, Annual financial report 2011-2015, November 2016

Table 3: Profitability ratios of the BPR Ltd.

\begin{tabular}{|c|c|c|c|c|c|c|}
\hline Liquidity ratios & Formula & 2015 & 2014 & 2013 & 2012 & 2011 \\
\hline Current Ratio & $\mathrm{CR}=\mathrm{CA} / \mathrm{CL}^{*} 100$ & 24.31 & 26.00 & 33.71 & 22.41 & 31.84 \\
\hline Acid Ratio & $A R=(C C E+S T I+A R) / C L * 100$ & 98.94 & 100.0 & 98.33 & 103.4 & 103.3 \\
\hline Total loans to Total Asset Ratio (TLTA) & TLTA=Total Loans/Total Assets & 69.83 & 68.18 & 63.74 & 74.49 & 65.38 \\
\hline Liquid Assets to Total Deposit Ratio (LATD) & LATD=Liquid Asset/Customer Deposit & 28.35 & 29.31 & 38.45 & 26.13 & 35.58 \\
\hline Total Loans to Deposit & TLTD=Total Loans/customer Deposit & 88.59 & 85.47 & 79.67 & 98.26 & 83.66 \\
\hline
\end{tabular}

Source: BPR, Annual financial report 2011-2015, November 2016

Table 4: Liquidity ratios of the BPR Ltd for the period of 5 years ended 31/12/2015. 
Citation: Harelimana JB (2017) Analysis of Financial Statements for Prediction of Business Sustainability in Rwanda: A Case of Banque Populaire Du Rwanda Ltd. Bus Eco J 8: 288. doi: 10.4172/2151-6219.1000288

Page 6 of 9

\begin{tabular}{|c|c|c|c|c|c|c|}
\hline Efficiency ratios & Formula & 2015 & 2014 & 2013 & 2012 & 2011 \\
\hline Efficiency Ratio & Total operating expenses/Total operational income & 81.88 & 67.85 & 91.43 & 83.34 & 85.66 \\
\hline Net Interest Income & Interest Expenses/Interest Income & 16.35 & 18.29 & 18.58 & 12.68 & 5.37 \\
\hline $\begin{array}{l}\text { Net Fee and Commission } \\
\text { Income }\end{array}$ & $\begin{array}{l}\text { Fee and Commission Expense/Fee and Commission } \\
\text { Income }\end{array}$ & 27.66 & 34.88 & 44.84 & 29.70 & 32.28 \\
\hline Accounts Payable Turnover & Interest Expenses/Average Accounts Payable & 1.83 & 1.94 & 2.24 & 2.30 & 2.89 \\
\hline Total Asset Turnover & Revenue (R)/Average Total Assets (ATA) & $(0.01)$ & 0.01 & $(0.03)$ & $(0.00)$ & 0.01 \\
\hline Accounts Receivable Turnover & Revenue/(Average Accounts Receivable) & (0.09) & 0.05 & $(0.16)$ & $(0.04)$ & 0.05 \\
\hline
\end{tabular}

Table 5: Efficiency ratios of the BPR Ltd for the period of 5 years ended 31/12/2015.

\begin{tabular}{|c|c|c|c|c|c|c|}
\hline Leverage ratios & Formula & 2015 & 2014 & 2013 & 2012 & 2011 \\
\hline Debt Ratio (DR) & Total Liabilities (TL)/Total Assets (TA) & 0.92 & 0.9 & 0.91 & 0.88 & 0.87 \\
\hline Debt-to-Equity (DtE) & Total Liabilities (TL)/Total Equity (TE) & 11.38 & 8.93 & 10.42 & 7.61 & 6.89 \\
\hline Equity Ratio (ER) & Total Equity (TE)/Total Assets (TA) & 8.08 & 10.07 & 8.75 & 11.61 & 12.67 \\
\hline Equity to Loan Ratio (EQL) & EQL=Total Equity/Total Loans & 11.57 & 14.77 & 13.73 & 15.59 & 19.38 \\
\hline Non- performing Loans to Total Loan Ratio (NPTL) & NPTL=Nonperforming Loans/Total Loans & 5.01 & 7.65 & 12.79 & 7.05 & 7.17 \\
\hline
\end{tabular}

Source: BPR, Annual financial report 2011-2015, November 2016

Table 6: Leverage ratios of the BPR Ltd for the period of 5 years ended 31/12/2015.

\begin{tabular}{|l|l|l|l|l|l|l|l|l|l|}
\hline $\begin{array}{l}\text { Market value } \\
\text { ratios }\end{array}$ & Formula & 2015 & 2014 & 2013 \\
\hline $\begin{array}{l}\text { Price-Earnings } \\
\text { Ratio (P/E Ratio) }\end{array}$ & $\begin{array}{l}\text { Price per share or Market Value Price per share/Earnings per share } \\
\text { Whereas, (Earnings per share=Net Income/Number of Shares Outstanding) }\end{array}$ & 8.35 & 18.15 & 2.96 \\
\hline $\begin{array}{l}\text { Market-to-Book } \\
\text { Ratio }\end{array}$ & $\begin{array}{l}\text { Price per share or Market Value Price per share/Book Value per share } \\
\text { Whereas, Book Value per share=Total Owners' Equity/Number of Shares } \\
\text { Outstanding }\end{array}$ & 1.19 & 1.04 & 20.07 \\
\hline Source: BPR Ltd, Annual financial report 2011-2015, November 2016 & 0.71 & 0.81 \\
\hline
\end{tabular}

Table 7: Market value ratios of the BPR Ltd for the period of 5 years ended 31/12/2015.

\begin{tabular}{|c|c|c|c|c|c|c|c|}
\hline Ratios & Computation & BNR Requirement & 2015 & 2014 & 2013 & 2012 & 2011 \\
\hline Capital Adequacy Ratio & Total capital/Total risk weighted assets & Min $15 \%$ & $2.96 \%$ & $1.57 \%$ & $1.13 \%$ & $2.05 \%$ & $4.36 \%$ \\
\hline $\begin{array}{l}\text { Core capital to risk } \\
\text { weighted assets (RWA) }\end{array}$ & Core capital/Total risk weighted assets & Min $10 \%$ & $3.52 \%$ & $1.64 \%$ & $1.25 \%$ & $1.65 \%$ & $3.37 \%$ \\
\hline
\end{tabular}

Table 8: Capital adjustments ratios for the period of 5 years ended 31/12/2015.

i. Regulatory capital (Total capital) divided by risk weighted assets (RWA) - CAR

ii. Core capital (Tier 1) to risk weighted assets (RWA) (Table 8).

By Business sustainability is often determined by as managing the triple bottom line a process by which companies manage their financial, social and environmental risks, obligations and opportunities. These three impacts are sometimes referred to as profits, people and planet. To analysis the BPR business sustainability in line of how company manages its financial opportunities, we focused on: Dividend Pay-out Ratio, Retention Rate or plowback ratio, Internal Growth Rate and Sustainable Growth Rate (Table 9).

From the table above, the results revealed that dividends Payout Ratio for BPR were $0 \%$ as no any dividend was distributed to the customer. In additional to, the result BPR Retention Ratio were negative as at $-1.00 \%$ for year 2015,2013 and 2012 , this indicated the percentage of a BPR's loss that are incurred in share value. For year 2014 and 2011, retention Ratio were $1.00 \%$. The results also showed that BPR internal growth rate were (7.62), 1.36, (1.44), 0.88 and (20.63) respectively for year 2015, 2014, 2013, 2012 and 2011 as the ratio expressing the maximum growth rate a firm can achieve without resorting to external financing. Sustainable growth for BPR as the annual percentage of increase in revenue that are inconsistent in accordance with a BPR defined financial policy.

According to the BPR sustainable growth rate as per research results were in (11.97), 5.51, (33.77), (4.98) and 10.74 respectively for year 2015, 2014, 2013, 2012 and 2011 as a determinant of the BPR's maximum growth rate in revenue using internal financial resources and without having to increase debt or issue new equity.

About $60 \%$ of the scope under study, the BPR has recognized losses. The shareholders do not earn dividends anymore. The calculated sustainability growth for BPR is critically and need other advance strategies to improve this situation and safeguard BPR public image such as capital adjustment and found other external resources.

\section{Analysis of financial indicators and sustainability determinants of BPR}

The efforts in this space are looked to scientific and statistically sound methods to demonstrate correlations between financial indicators for predicting sustainability determinants of BPR. With this, the analysis began with correlation testing of financial indicators against sustainability determinants followed by statistical hypothesis testing to see if we can definitively point to the most appropriate indicators.

The F-test was carried out to test the significance of the regression model in predicting the dependent variable (business sustainability). 


\begin{tabular}{|c|c|c|c|c|c|c|c|}
\hline & & & 2015 & 2014 & 2013 & 2012 & 2011 \\
\hline $\begin{array}{l}\text { Dividend Pay-out } \\
\text { Ratio }\end{array}$ & Pay-out Ratio & Total Dividends Paid/Net Income & - & - & - & - & - \\
\hline $\begin{array}{l}\text { Retention Rate or } \\
\text { plowback ratio }\end{array}$ & Retention Rate $=$ & (Net Income - Dividends Distributed)/Net Income & 1 & 1 & 1 & 1 & 1 \\
\hline $\begin{array}{l}\text { Internal Growth } \\
\text { Rate }\end{array}$ & $\begin{array}{l}\text { Internal Growth rate } \\
\text { (IGR) }\end{array}$ & $\begin{array}{l}\text { ROA x Retention Ratio/(1-(ROA x Retention Ratio) } \\
\text { Whereas: ROA=Net Profit/Total of Assets of the firm } \\
\text { Retention Ratio=1 - Dividend pay-out of the firm }\end{array}$ & 7.62 & 1.36 & 1.44 & 0.88 & 20.63 \\
\hline $\begin{array}{l}\text { Sustainable Growth } \\
\text { Rate }\end{array}$ & $\begin{array}{l}\text { Sustainable Growth } \\
\text { Rate }\end{array}$ & SGR=Return in Equity *(1-Dividend Pay-out Ratio) & 11.97 & 5.51 & 33.77 & 4.98 & 10.74 \\
\hline
\end{tabular}

Table 9: Analysis determinants of business sustainability of BPR Ltd.

From the results, it was found that the five independent variables (Profitability ratios, Liquidity Ratios; Efficiency ratios, Leverage ratios and Market value ratios) as financial indicators of BPR Ltd (adjusted $R$ squared $=0.726$ ). That means the model explains $72.6 \%$ the variance in the business sustainability of BPR Ltd (27.4\%) of variations are brought about by factors not captured in the objectives. Therefore, further research should be conducted to analyze the other factors $(27.4 \%)$ that affect prediction of business sustainability of the BPR Ltd. The regression equation appears to be very useful for making predictions since the value of $R^{2}$ is close to 1 .

The findings shows that the linear regression $\mathrm{F}$-test results $(\mathrm{F}=8.741$; and $5 \mathrm{df})$ are significant at $\mathrm{p}<0.05$, therefore, the hypothesis was positive for the researcher. But counting that BPR is earning, instead of a complete positive relationship, there are indications that the positive relationship is only true for low and moderate sustainability of business. Therefore, the hypothesis concluded that the regression model linearly explains the determinants for prediction of business sustainability of the BPR Ltd. Therefore, the study accepted the alternative hypothesis.

- Profitability ratios, liquidity ratios; efficiency ratios, leverage ratios and market value ratios are the indicators of financial analysis of BPR.

- Pay-out ratio, retention ratio, internal growth rate and sustainable growth rate are the factors of the BPR business sustainability.

- The financial indicators explain positively the prediction of business sustainability in BPR Ltd.

The study conducted a multiple regression analysis so as to determine the regression coefficients $(\beta)$ which shows that $\beta_{0}=1.238$ and which means that all the independent variables such as profitability ratios $\left(\mathrm{X}_{1}\right)$, Liquidity Ratios $\left(\mathrm{X}_{2}\right)$; Efficiency ratios $\left(\mathrm{X}_{3}\right)$, Leverage ratios $\left(\mathrm{X}_{4}\right)$ and Market value ratios $\left(\mathrm{X}_{5}\right)$ have an a significant contribution in prediction of business sustainability even if the $\mathrm{x}$ variable equal to zero means $\mathrm{Y}=1.238$ and the model equation become $\mathrm{Y}=1.238+$ $0.258 \mathrm{X}_{1}+0.367 \mathrm{X}_{2}+0.423 \mathrm{X}_{3}+0.157 \mathrm{X}_{4}+0.345 \mathrm{X}_{5}$. Hence, $\beta 0=$ Constant term $\beta(1-5)=$ represent the model parameters or coefficients; 0.258 as contribution of profitability ratios, .367 as contribution from Liquidity Ratios, .423 contribution of Efficiency ratios, .157 contribution of Leverage ratios and .345 as Market value ratios contribution.

\section{Prediction of financial statement of BPR Ltd for three years (2016-2018)}

The BPR Ltd has started to re-capitalize its Share capital for competitiveness with other commercial bank, and some change in management and shareholders structure was made [3]. While developing the financial predictions, the following was the considered rationale for the predictions:

1. The key driver of the growth will be the deposits. The bank endeavors to grow its deposit annually initially by $10 \%$ and stabilize at $12.5 \%$ by 2018 .

2. The deposits should make available funds that are key to the growth of the loan portfolio. These will be based on the assumption of a stable economic growth averaging $7.5 \%$ and a steady inflation rate of $7.5 \%$ and/or below throughout the plan period.

3. The interest on loans should be a key revenue source. The current base interest rate is $19 \%$. We have prudently predicted the rate to reduce to $17.5 \%$ in 2018 due to declining treasury bills rate.

4. The commission income has been derived as a factor of number of active customer accounts currently standing at 400,000. The growth of the active accounts is expected to grow in line with deposits growth.

5. The efficiency rate will be expected to move from $81.88 \%$ in 2015 to $76 \%$ by 2018 . This will mainly be triggered by faster income growth rate as compared to costs growth rate. Implementation of IT systems will increase efficiency hence operational costs will increase relative to the inflationary rate.

6. Personnel costs should got up due to competition with market for best talent. The staff costs is predicted to grow at $5 \%$ annually while the training expense should grow up $50 \%$ this especially related to automation of systems as now BPR was upgraded from T12 to R12 as per the interview with the Board of directors.

7. We predicted the new investment in assets of over 12 billion spread over the plan period. Intangible assets amount to 3.7 billion. The remaining amount will be used to purchase fixed assets. Over 5.8 billion of the investment will be on buildings (New head office building and refurbishment/relocation of branches). New Head Office building construction will be undertaken from 2013 to 2016 while payments will be spread from 2016 to 2018 .

8. Nonperforming loans was predicted to remain within $5.01 \%$ mainly through growing the loan book, enhancing recovery and improving the quality of loan book. Provisions for impairment loss on NPLs should set at 55\% of the NPLs from 2015 up to 2018.

9. Dividends should be introduced in 2016 and calculated based on $25 \%$ of profits, and remain as reserves and

Base on the financial current financial information, the prediction of financial statement of BPR Ltd should look like as follows:

The BPR Ltd should recognize the net comprehensive income of Frw1, 768,009 in 2016, Frw2, 754,138 in 2017, and Frw4, 062,098. This 
comprehensive income was predicted after the distribution of dividend payout ratios and tax expenses. The gross operating income with move at Frw26, 139,939, Frw28, 323,593, and Frw31, 197,637 respectively in year of 2016, 2017, and 2018. And as well the Total operating expenses should be as Frw23, 772,303, 23,077,615, and Frw23, 460,308 respectively with year of 2016, 2017 and 2018. This should improve the BPR Ltd's efficiency and profitability ratios and also improve the sustainability of the BPR Ltd of market.

The BPR Ltd also should recognize the total liabilities and equity of Frw219,910,083 in 2016, Frw239,778,902 in 2017, and Frw265,496,753 as well as the same figure for total asset as the financial position might balance. The liquidity and leverage ratios might be improved from the new injected capital, as well as new management. Now, the BPR has recapitalized from frw16,491,238 to Frw43,519,181 after injecting the new investor "Atalasmara", the prediction was done with assumption that the share capital is constant. The BPR Ltd should recognize the Total liabilities and equity of Frw3,942,067 in 2016, Frw6,696,205 in 2017, and Frw10,758,302 for 2018. The upgrading of reserves may positively impact the BPR internal growth and sustainability growth.

\section{Conclusion and Recommendation}

\section{Conclusions}

The analysis done so far has been related to the financial statement for prediction of business sustainability in Rwanda with a case of Banque populaire du Rwanda (BPR). BPR is the bank whose target market is the grassroots and maintains the lead in the segment. The bank was transformed to a commercial bank in 2008 with a vision "To be the leading retail bank in Rwanda". It is in competition with other commercial banks which have more than 30 year in this sector of commercial bank. The findings from analysis of financial statements for prediction of business sustainability of BPR Ltd were concentrated on Profitability ratios, Liquidity Ratios; efficiency ratios, leverage ratios and market value ratios as indicators of financial analysis of BPR; Payout ratio, retention ratio, internal growth rate and sustainable growth rate as determinants of the BPR business sustainability. The financial analysis indicators explain positively the prediction of business sustainability determinants in BPR Ltd.

The profitability ratios have indicated that the ability of BPR to earn profit is on low level where 3 to 5 years with $60 \%$ BPR made a loss. BPR to pay short term obligations are not sufficient comparing the minimum and maximum requirements rate of BNR. BPR Ltd was sometimes unable to use its assets and manage its liabilities effectively. The ability of BPR to meet financial obligations, both long-term and short-term creditors are insignificant, the NPL rate of over rate 5\% obliged by the BNR and finally the Market value ratios were indicated an adverse relationship between the price per share and its earnings, growth and assets for the BPR Ltd. The Capital Adequacy of BPR cannot absorb a reasonable amount of loss and is not complied with statutory capital requirements by the BNR. The result revealed that $\mathrm{BPR}$ is exposed on the risks from taking excess leverage and becoming insolvent in the process.

The results revealed that dividends Pay-out Ratio for BPR were $0 \%$ as no any dividend was distributed to the customer. In additional to, the result BPR Retention Ratio were negative as at $-1.00 \%$ for year 2015, 2013 and 2012, this indicated the percentage of a BPR's loss that are incurred in share value. For year 2014 and 2011, retention Ratio were $1.00 \%$. The results also showed that BPR internal growth rate were (7.62), 1.36, (1.44), 0.88 and (20.63) respectively for year 2015, 2014, 2013,2012 and 2011 as the ratio expressing the maximum growth rate a firm can achieve without resorting to external financing. Sustainable growth for BPR as the annual percentage of increase in revenue that are inconsistent in accordance with a BPR defined financial policy.

According to the BPR sustainable growth rate as per research results were in (11.97), 5.51, (33.77), (4.98) and 10.74 respectively for year 2015, 2014, 2013, 2012 and 2011 as a determinant of the BPR's maximum growth rate in revenue using internal financial resources and without having to increase debt or issue new equity.

About $60 \%$ of the scope under study, the BPR has recognized losses. The shareholders do not earn dividends anymore. The calculated sustainability growth for BPR is critically and need other advance strategies to improve this situation and safeguard BPR public image such as capital adjustment and found other external resources. To measure the relationship between financial indicators for prediction sustainability, the hypothesis was positive for the researcher. Therefore, the hypothesis concluded that the regression model linearly explains the determinants for prediction of business sustainability of the BPR Ltd. The alternative hypothesis was accepted.

To summarize, financial statement analysis was concerned with analyzing the financial position and the income statement of the BPR to interpret the business and financial ratios of a business for financial representations, business evaluation, and give a recommendation for forecasting its business sustainability.

\section{Recommendations}

From the above analysis it is recommended that BPR should start the recapitalization processes from Frw15,300 billion to Frw16,491 billion, and now Frw43.519 billion. But till now this capital is not yet adequate for competing with other commercial bank with a total Shareholders' equity more than 60.3 billion, such as BK, KCB, and others with more than Frw45 billion such as GT-Bank and I\&M Bank. It is better for recapitalization of BPR Ltd Frw43.519 billion to Frw63.519 billion from potential local and/or foreign investors who share the same vision with BPR. Cost cut-off of unnecessary expenses and reduce high fixed costs related to extensive network. BPR has to centralize management of loans recovery to enhance efficiency.

BPR must grow in net revenues from loans and advances to customer, Net assets and profits. Continuing growth means increasing loan portfolio quality and therefore taking advantage to reduce per unit cost thereby increasing profits. Revamping the IT systems to better serve its mass customers on high satisfactory level and for better management and controls; Developing new competitive products to for customer need and profit realization; To continue growing its channels such growth in the Agency Banking, ATMs, internet and mobile banking channels; Restoration its public image by constructing a new head office, refurbishing rundown branches and relocating branches that are far from business areas and outside strategic business areas.

BPR should extend its reach to mass market through strategic partnerships with telecommunications companies, electronic transfer agencies. It should introduce mobile powered products in the market in order to tap into the power of the more than 6 million mobile phone users in the Rwandan market. Partnership with Government/ Development partners that focus on the bottom of the pyramid. BPR should attract, develop and retain the best talent staff in the market for quality service delivery; and controls and operational efficiency by fully automation of payment processes. BPR's product lines have real growth 
Citation: Harelimana JB (2017) Analysis of Financial Statements for Prediction of Business Sustainability in Rwanda: A Case of Banque Populaire Du Rwanda Ltd. Bus Eco J 8: 288. doi: 10.4172/2151-6219.1000288

Page 9 of 9

potential and our strategy is to concentrate the available resources on growth both in reach and depth of BPR operations to ensure that they continue to be successful.

The Government of Rwanda through BNR as financial regulator should conduct a continuous assessment of potential systemic risks to the Rwandan financial system and the development of policies to mitigate those risks. Government of Rwanda should be directly involved to help eliminate the financing gap faced by BPR through direct government interventions through public banks, credit guarantee schemes and other forms of subsidized financing.

The BNR should enhance a stable financial system which creates a favorable environment for savers and investors, encourages efficient financial intermediation and the effective functioning of markets, and hence, promotes investment and economic growth.

Further research should look on other variables rather than financial indicators and the business sustainability determinates. In addition, a researcher should put emphasis on analysis of financial statements for all financial system stability in Rwanda.

\section{References}

1. Bourne M, Mills J, Wilcox M, Neely A, Platts K (2000) Designing, implementing and updating performance measurement systems. International Journal of Operations and Production Management 20: 754-771.

2. Otley D (2003) Measuring Performance, the Accounting Perspective in Business Performance Measurement, Theory and Practice Edited by Andy Neely. Cambridge University Press.
3. BPR (2013) Strategic and business plan Kigali. Rwanda.

4. HARELIMANA JB (2014) Analyse de la performance financière et de la performance Sociale des institutions de microfinance au Rwanda. P: 567.

5. Gakuya F, Ombui J, Maingi N, Muchemi G, Ogara W et al. (2012) Sarcoptic mange and cheetah conservation in Masai Mara (Kenya): epidemiological study in a wildlife/livestock system. Parasitology 139: 1587-1595.

6. Almazari AA (2011) Financial performance evaluation of some selected Jordanian commercial banks. International Research Journal of Finance and Economics 68: 50-63.

7. Wozniewska G (2015) Methods of measuring the efficiency of commercial banks: an example of Polish banks. Ekonomika. 85: 81-91.

8. Acemoglu D, Johnson S, Robinson JA (2002) Reversal of fortune: Geography and institutions in the making of the modern world income distribution. National bureau of economic research.

9. Hakensen D (2010) Sustainability defined. Minnesota Business.

10. Moh'd Al-Tamimi KA, Obeidat SF (2013) Determinants of capital adequacy in commercial banks of Jordan an empirical study. International Journal of Academic Research in Economics and Management Sciences 2: 44.

11. James T (1918) An Appreciation Of His Contribution To Economics. Economic Journal.

12. Siddique HR, Saleem M (2011) Beneficial health effects of lupeol triterpene: a review of preclinical studies. Life Sciences 88: 285-293.

13. Chary NS, Kamala CT, Raj DSS (2008) Assessing risk of heavy metals from consuming food grown on sewage irrigated soils and food chain transfer. Ecotoxicology and Environmental Safety 69: 513-524.

14. Nobes C, Parker RH (2008) Comparative international accounting. Pearson Education. 